\title{
Genetic Alterations In Turkish Patients With Multiple Myeloma: A Single Center Experience
}

\section{Türk Multiple Myeloma Hastalarındaki Genetik Bozukluklar: Tek Merkez Deneyimi}

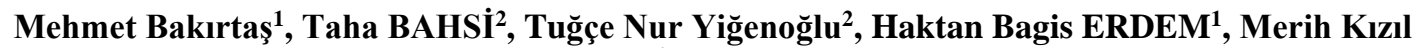 \\ Çakar' $^{1}$, MEHMET SINAN DAL ${ }^{1}$, Fevzi Altuntaş ${ }^{1}$ \\ ${ }^{1}$ Hematoloji ve Kemik İliği Nakil Birimi, Ankara Dr Abdurrahman Yurtaslan Onkoloji Eğitim ve Araştırma Hastanesi, \\ Sağlık Bilimleri Üniversitesi, Ankara, Türkiye \\ ${ }^{2}$ Genetik Departmanı, Ankara Dr Abdurrahman Yurtaslan Onkoloji Eğitim ve Araştırma Hastanesi, Sağlık Bilimleri \\ Üniversitesi, Ankara, Türkiye
}

Dergiye Ulaşma Tarihi: 07.07.2020 Dergiye Kabul Tarihi: 10.07.2020 Doi: 10.5505/aot.2020.02439

\section{ÖZET}

GİRİŞ ve AMAÇ: Multipl Miyelom (MM) ikinci en sı görülen hematolojik malignitedir. MM'deki genetik değişiklikler kromozomların yapısını veya sayısını etkileyebilir. t (11;14) (q13; q32), t (4; 14) (p16; q32), t (14; 16) (q23; q32), hipodiploidi, hiperdiploidi, delesyon 13q (del 13q) veya TP53, MM hastalarında gözlenen mutasyonlardan bazılarıdır. Bu çalışmada, myelomalı Türk hastalarda gözlenen genetik değişiklikleri incelemeyi amaçladık.

YÖNTEM ve GEREÇLER: Şubat 2014 ile Kasım 2019 tarihleri arasında merkezimizde genetik değerlendirmesi yapılan MM hastalarının verileri retrospektif olarak incelendi. Yalnızca kemik iliği örnekleri konvansiyonel sitogenetik ve floresan yerinde hibridizasyon (FISH) [t $(4 ; 14), \mathrm{t}(11 ; 14)$, del13q, TP53] ile değerlendirilen hastalar çalışmaya dahil edildi.

BULGULAR: Çalışmaya 100 MM hastası dahil edildi. 22 (\% 22) hastada tanı anında genetik değişiklikler görüldü. En sık görülen genetik değişiklik hastaların\% 12 'sinde görülen del13q idi. MM hastalarının \% 8'inde $\mathrm{t}$ (11; 14), \% 8'inde TP53, \% 7'sinde trizomi 7, \% 5'inde t $(4 ; 14)$ ve \% 4'ünde trizomi 8 gözlenmiştir.

TARTIŞMA ve SONUÇ: Tedavi yaklaşımlarını optimize etmek için MM hastalarının genetik özelliklerinin sadece tanı anında değil takip sırasında da değerlendirilmesi önemlidir.

Anahtar Kelimeler: Multipl myelom, genetik değişiklikler, konvansiyonel sitogenetik

\section{ABSTRACT}

INTRODUCTION: Multiple Myeloma (MM) is the second most common hematologic malignancy. Genetic alterations in $\mathrm{MM}$ may affect structure or number of chromosomes. Specific translocations like $\mathrm{t}(11 ; 14)(\mathrm{q} 13 ; \mathrm{q} 32), \mathrm{t}(4 ; 14)(\mathrm{p} 16 ; \mathrm{q} 32), \mathrm{t}(14 ; 16)(\mathrm{q} 23 ; \mathrm{q} 32)$, hypodiploidy, hyperdiploidy, deletion 13q (del 13q) or TP53 are some of the mutations observed in MM patients. In this study, we aimed to study the genetic alterations observed in Turkish patients with MM.

METHODS: The data of MM patients whose genetic evaluations were performed at our center between February 2014 and November 2019 were retrospectively analyzed. Only the patients whose bone marrow samples were evaluated by conventional cytogenetics and by fluorescence in situ hybridization (FISH) $[\mathrm{t}(4 ; 14), \mathrm{t}(11 ; 14)$, del13q, TP53] were included in the study.

RESULTS: 100 patients with MM were included in the study. $22(22 \%)$ patients had genetic alterations at the time of diagnosis. The most often observed genetic alteration was del $13 \mathrm{q}$ which was observed in $12 \%$ of the patients. $\mathrm{t}(11 ; 14)$, TP53, trisomy $7, \mathrm{t}(4 ; 14)$ and trisomy 8 were observed in $8 \%, 8 \%, 7 \%, 5 \%$ and $4 \%$ of $\mathrm{MM}$ patients, respectively.

DISCUSSION AND CONCLUSION: Evaluating the genetic characteristics of MM patients not only at the time of diagnosis but also during the follow up is crucial in order to optimize the treatment aproaches. Keywords: Multiple myeloma, genetic alterations, conventional cytogenetics

Keywords: Multiple myeloma, genetic alterations, conventional cytogenetics 


\section{INTRODUCTION}

Multiple myeloma (MM) is a plasma cell malignancy in which clonal plasma cells produce a monoclonal immunoglobulin. MM is the second most common hematologic malignancy. Median age at diagnosis is 70 years and two-thirds of the patients are older than 65 years. MM patients usually present with skeletal destruction with osteolytic lesions, pathologic fractures, hypercalcemia, renal insufficiency and anemia $(1,2)$.

The etiology of MM has been under investigation for decades but the exact cause is still unknown. The pathogenesis of MM patients starts from genomic changes. The factors that start these genomic changes has not been identified yet. The earliest phase of $\mathrm{MM}$ is monoclonal gammopathy of undetermined significance (MGUS). There is an asymptomatic expansion of clonal plasma cells in MGUS and the risk of MGUS patients for progressing to $\mathrm{MM}$ is $1 \%$ per year $(3,4)$. The phase between MGUS and MM is smoldering MM (SMM) and the risk of SMM patients for progressing to MM is $10 \%$ per year for the first five years (5). So some patients with MGUS or SMM progress to MM, but most of the patients remain without progression. The question that must be answered is which factor triggers the progression to MM from MGUS or SMM. The answer is still unknown but the main hypothesis is the occurrence of a genetic alteration that cause carcinogenesis leading progression to MM. With the improvements in the field of genetic, many genetic alterations that cause MM have now been characterised and they have been used to categorise patients according to their genetic risk classification. So genetic evaluation of every MM patient is very important in order to understand the disease aggressiveness and to plan treatment aproaches (3-5).

Genetic alterations in MM may affect structure or number of chromosomes. Specific translocations like $\mathrm{t}(11 ; 14)(\mathrm{q} 13 ; \mathrm{q} 32)$, $\mathrm{t}(4 ; 14)(\mathrm{p} 16 ; \mathrm{q} 32), \quad \mathrm{t}(14 ; 16)(\mathrm{q} 23 ; \mathrm{q} 32)$, hypodiploidy, hyperdiploidy, deletion $13 \mathrm{q}$ (del $13 q)$ or TP53 are some of the mutations observed in MM patients (6). In this study, we aimed to study the genetic alterations observed in Turkish patients with MM.

\section{MATERIAL AND METHOD}

The data of MM patients who were treated at our center between February 2014 and November 2019 were retrospectively analyzed. Only the patients whose bone marrow samples were evaluated by conventional cytogenetics and by fluorescence in situ hybridization (FISH) $[\mathrm{t}(4 ; 14), \mathrm{t}(11 ; 14)$, del13q, TP53] were included in the study. The patients who had missing data of conventional cytogenetic or $\mathrm{t}(4 ; 14), \mathrm{t}(11 ; 14)$, del13q and TP53 by FISH were excluded from the study. In order to study conventional cytogenetics (chromosome analysis), after the bone marrow samples of patients reached to genetic laboratory, direct cell cultures were performed from the samples. $20 \%$ fetal calf serum and antibiotic were added to the samples and cultures were performed on RPMI medium. Mitogen agents were not added to cultures. Then the harvesting was carried out according to routine methods and the spreading process was performed. Finally, the preparations were made ready for analysis by GTG banding. Chromosome analysis was performed with computer aided software under microscope according to ISCN (International System of Human Cystogenetic Nomenclature) on at least 20 metaphases. When sufficient number of metaphase was not obtained, analysis was made on the number of metaphases obtained. In order to use molecular cytogenetic (FISH) method; smears were made with fixatives obtained from bone marrow samples and genomic changes were analyzed by fluorescence microscope using probes specific to $\mathrm{t}(4 ; 14), \mathrm{t}(11 ; 14)$, del13q and TP53 regions. In addition, after the amplification by polymerase chain reaction (PCR) technique for detection of $\mathrm{t}(11 ; 14)$ change, DNA execution was performed on gel electrophoresis and analyzed.

The statistical analyses were performed with SPSS V21.0 (SPSS Inc., Chicago, IL) software. Descriptive statistics were used to summarize the data.

\section{RESULTS}

100 patients with MM were included in the study. $22(22 \%)$ patients had genetic alterations at the time of diagnosis. The most often observed genetic alteration was del13q which was observed in $12 \%$ of the patients. In 
3 patients there were 5 genetic alterations together at the time of diagnosis. Except these 22 patients who had genetic alterations at the time of diagnosis, 4 patients had genetic alterations during follow up unless they had no genetic alterations at the time of diagnosis. The prevalances of genetic alterations observed in patients were given in Table 1 and the genetic characteristics of the patients were given in Table 2.

Table 1. Prevalances of genetic alterations

\begin{tabular}{|l|l|}
\hline Genetic alterations & Patients (\%) \\
\hline del $13 \mathrm{q}$ & $12 \%$ \\
\hline TP53 & $8 \%$ \\
\hline $\mathrm{t}(11,14)$ & $8 \%$ \\
\hline $\mathrm{t}(4,14)$ & $5 \%$ \\
\hline trisomy 7 & $7 \%$ \\
\hline trisomy 8 & $4 \%$ \\
\hline
\end{tabular}

Table 2. Genetic characteristics of the patients

\begin{tabular}{|l|l|}
\hline $\begin{array}{l}\text { Number of } \\
\text { patients }\end{array}$ & Genetic alterations \\
\hline $\mathrm{n}: 6$ & del 13q \\
\hline $\mathrm{n}: 3$ & $T P 53$ \\
\hline $\mathrm{n}: 2$ & $T P 53$ and $\mathrm{t}(11,14)$ \\
\hline $\mathrm{n}: 2$ & trisomy 7 \\
\hline $\mathrm{n}: 1$ & $\mathrm{t}(11,14)$ \\
\hline $\mathrm{n}: 1$ & $T P 53$ and $\mathrm{t}(4,14)$ \\
\hline $\mathrm{n}: 1$ & trisomy 8, del 13q \\
\hline $\mathrm{n}: 1$ & trisomy 7, trisomy 8, del 13q \\
\hline $\mathrm{n}: 1$ & del 13q, $\mathrm{t}(11,14), \mathrm{t}(4,14)$ \\
\hline $\mathrm{n}: 1$ & trisomy 7, del 13q, $\mathrm{t}(11,14)$ \\
\hline $\mathrm{n}: 1$ & $\begin{array}{l}\text { trisomy 7, trisomy 8, } \mathrm{t}(11,14), \\
\mathrm{t}(4,14), T P 53\end{array}$ \\
\hline $\mathrm{n}: 1$ & $\begin{array}{l}\text { trisomy 7, del 13q, } \mathrm{t}(11,14), \\
\mathrm{t}(4,14), T P 53\end{array}$ \\
\hline $\mathrm{n}: 1$ & $\begin{array}{l}\text { trisomy 7, trisomy 8, del 13q, } \\
\mathrm{t}(11,14), \mathrm{t}(4,14)\end{array}$ \\
\hline
\end{tabular}

\section{DISCUSSION}

Multiple Myeloma is an older age disease. The patiens have been long living with the novel agents such as lenalidomide, pomalidomide, monoclonal antibodies and protesome inhibitors. Although various side effects of these novel agents have been widely observed, they could be managable (7). Genetic alterations in Multiple Myeloma are important prognostic factors and their importance in clinical practice have been increasing.
The most common genetic alterations observed in monoclonal plasma cells at the time of diagnosis are monosomy 13, chromosome 1q gains and different deletions involving the 1p, 6q, 8p, 12p, 14q, 16q, 17p, or $20 \mathrm{p}$ chromosomal regions (8-10). In our study. $22 \%$ of patients had genetic alterations at the time of diagnosis and the most often observed genetic alteration was del 13q.

$40-50 \%$ of genomic changes in MM patients at the time of diagnosis are chromosomal translocations (11). $\mathrm{t}(11 ; 14)(\mathrm{q} 13 ; \mathrm{q} 32) \quad$ dysregulates the $C C N D 1$ gene and it is observed in $15 \%$ to $20 \%$ of MM patients (12). In our study, $\mathrm{t}(11 ; 14)$ was observed in $8 \%$ of MM patients. Except 1 patient, all patients with $\mathrm{t}(11 ; 14)$ had additional genetic alterations.

The second most offen immunoglobulin heavy chain translocation is the $\mathrm{t}(4 ; 14)(\mathrm{p} 16 ; \mathrm{q} 32)$ and it is observed in $12 \%$ to $15 \%$ of MM patients (13). $t(4 ; 14)$ cause overexpression of $F G F R 3$ and MMSET (14). In previous studies $t(4 ; 14)$ has been shown to be related with an adverse prognosis $(15-17)$. In our study, $\mathrm{t}(4 ; 14)$ was observed in 5\% of MM patients and all of these patients had additional genetic alterations.

TP53 gene has a role in DNA repair and apoptosis in response to DNA damage. In previous studies, del(17p) has been found to be associated with an aggressive disease phenotype and poor survival (18). The gene deregulated in del(17p) is thought to be the tumour suppressor gene TP53, as it has been shown that $17 \mathrm{p}$ deletions express significantly less TP53 compared to nondeleted samples (19). In cases without del(17p) the rate of TP53 mutation is $<1 \%$, whereas in cases with $\operatorname{del}(17 p)$ this rises to $25-37 \%(20,21)$. In our study, TP53 mutation was observed in $8 \%$ of MM patients and all of these patients had additional genetic alterations. Further analysis to observe the possible relations of hemogram parameters and plasma cell ratio with these mutations may also be helpfull for prognosis evaluations in hematological malignancies (22).

Chromosome 13 deletion is observed in approximately $50 \%$ of patients with $\mathrm{MM}$ (23). In approximately $85 \%$ of cases, deletion of chromosome 13 constitutes a monosomy or 
loss of the $\mathrm{q}$ arm, whereas in the remaining $15 \%$ various interstitial deletions ocur (24). In our study, del 13 was observed in $12 \%$ of MM patients. In $90 \%$ of patients with del 13q, there is also $t(4 ; 14)(25)$. In our study, $50 \%$ of patients with del 13q, there was additional genetic alterations and in $25 \%$ of patients with del 13 , there was also $t(4 ; 14)$.

Genetic alterations in MM may affect structure or number of chromosomes. Hyperdiploidy involves trisomies of the odd numbered chromosomes and is observed in $50 \%$ of patients with MM. Hyperdiploidy is more common in elderly patients and is associated with a relatively favourable prognosis (26). In our study, $7 \%$ of patients had trisomy 7 and $4 \%$ of patients had trisomy 8 .

In conclusion; the prognosis in $\mathrm{MM}$ is very heterogeneous. Evaluating the genetic characteristics of MM patients not only at the time of diagnosis but also during the follow up is crucial in order to optimize the treatment aproaches.

\section{REFERENCES}

1. Palumbo A, Cavallo F. Have drug combinations supplanted stem cell transplantation in myeloma? Hematology Am Soc Hematol Educ Program 2012; 2012: 335-341.

2. Harousseau JL. Autologous transplantation for multiple myeloma. Ann Oncol 2008; 19: vii128-vii133.

3. R. A. Kyle, T. M. Therneau, S. V. Rajkumar et al., "Prevalence of monoclonal gammopathy of undetermined significance,"The New England Journal of Medicine, vol. 354, no. 13, pp. 1362-1369, 2006.

4. R. A. Kyle, T. M. Therneau, S. Vincent Rajkumar et al., "A long-term study of prognosis in monoclonal gammopathy of undetermined significance," The New England Journal of Medicine, vol. 346, no. 8, pp. 564569, 2002.

5. R. A. Kyle, E. D. Remstein, T. M. Therneau et al., "Clinical course and prognosis of smoldering (asymptomatic) multiple myeloma," The New England Journal of Medicine, vol. 356, no. 25, pp. 2582-2590, 2007.

6. Munshi N, Loiseau H. Genomics in multiple myeloma. Clin Cancer Res. 2011 March 15; 17(6): 1234-1242. doi:10.1158/1078-0432.CCR-10-1843.

7. Batgi H, Sinan Dal M, Merdin A, Kızıl Çakar M, Yiğenoğlu TN, Altuntaş F. A multiple myeloma patient who developed ischemic colitis during lenalidomide treatment: A rare case report [published online ahead of print, 2020 Feb 6]. J Oncol Pharm Pract.

2020;1078155219900910. doi:10.1177/1078155219900910

8. Avet-Loiseau H, Attal M, Moreau P, et al. Genetic abnormalities and survival in multiple myeloma: the experience of the Intergroupe Francophone du Myélome. Blood. 2007;109(8):3489-3495.

9. Hanamura I, Stewart JP, Huang Y, et al. Frequent gain of chromosome band 1q21 in plasma-cell dyscrasias detected by fluorescence in situ hybridization: incidence increases from MGUS to relapsed myeloma and is related to prognosis and disease progression following tandem stem-cell transplantation. Blood. 2006;108(5):17241732 .

10. Avet-Loiseau H, Li C, Magrangeas F, et al. Prognostic significance of copy-number alterations in multiple myeloma. J Clin Oncol. 2009;27(27):45854590.

11. W. M. Kuehl and P. L. Bergsagel, "Early genetic events provide the basis for a clinical classification of multiple myeloma," Hematology, pp. 346-352, 2005.

12. Chesi M, Bergsagel PL, Brents LA, Smith CM, Gerhard DS, Kuehl WM. Dysregulation of cyclin D1 by translocation into an IgH gamma switch region in two multiple myeloma cell lines. Blood. 1996;88(2):674681.

13. Hurt EM, Wiestner A, Rosenwald A, et al. Overexpression of $c$-mafis a frequent oncogenic event in multiple myeloma that promotes proliferation and pathological interactions with bone marrow stroma. Cancer Cell. 2004;5(2):191-199.

14. M. Chesi, E. Nardini, R. S. C. Lim, K. D. Smith, W. Michael Kuehl, and P. L. Bergsagel, "The $\mathrm{t}(4 ; 14)$ translocation in myeloma dysregulates both FGFR3 and a novel gene, MMSET, resulting in IgH/MMSET hybrid transcripts," Blood, vol. 92, no. 9, pp. 3025-3034, 1998. 15. F. Zhan, Y. Huang, S. Colla et al., "The molecular classification of multiple myeloma," Blood, vol. 108, no. 6, pp. 2020-2028, 2006.

16. J. J. Keats, T. Reiman, C. A. Maxwell et al., "In multiple myeloma, $\mathrm{t}(4 ; 14)(\mathrm{p} 16 ; \mathrm{q} 32)$ is an adverse prognostic factor irrespective of FGFR3 expression," Blood, vol. 101, no. 4, pp. 1520-1529, 2003.

17. R. Fonseca, E. Blood, M. Rue et al., "Clinical and biologic implications of recurrent genomic aberrations in myeloma," Blood, vol. 101, no. 11, pp. 4569-4575, 2003. 18. J. Drach, J. Ackermann, E. Fritz et al., "Presence of a p53 gene deletion in patients with multiple myeloma predicts for short survival after conventional-dose chemotherapy," Blood, vol. 92, no. 3, pp. 802-809, 1998. 19. B. A. Walker, P. E. Leone, L. Chiecchio et al., "A compendium of myeloma-associated chromosomal copy number abnormalities and their prognostic value," Blood, vol. 116, no. 15, pp. e56-e65, 2010.

20. L. Lode, M. Eveillard, V. Trichet et al., "Mutations in TP53 ' are exclusively associated with del(17p) in multiple myeloma," Haematologica, vol. 95, no. 11, pp. 1973-1976, 2010.

21. R. E. Tiedemann, N. Gonzalez-Paz, R. A. Kyle et al., "Genetic aberrations and survival in plasma cell leukemia," Leukemia, vol. 22, no. 5, pp. 1044-1052, 2008.

22. Merdin A, Dal MS, Çakar MK, et al. Analysis of prechemotherapy WBC, PLT, monocyte, hemoglobin, and MPV levels in acute myeloid leukemia patients with WT1, FLT3, or NPM gene mutations. Medicine (Baltimore). 2020;99(14):e19627. doi:10.1097/MD.0000000000019627

23. L. Chiecchio, R. K. M. Protheroe, A. H. Ibrahim et al., "Deletion of chromosome 13 detected by 
conventional cytogenetics is a critical prognostic factor in myeloma," Leukemia, vol. 20, no. 9, pp. 1610-1617, 2006.

24. H. Avet-Loiseau, A. Daviet, S. Saunier, and R. Bataille, "Chromosome 13 abnormalities in multiple myeloma are mostly monosomy 13," British Journal of Haematology, vol. 111, no. 4, pp. 1116-1117, 2000.

25. R. Fonseca, P. L. Bergsagel, J. Drach et al., "International Myeloma Working Group molecular classification of multiple myeloma: spotlight review," Leukemia, vol. 23, no. 12, pp. 2210-2221, 2009.
26. N. V. Smadja, C. Bastard, C. Brigaudeau, D. Leroux, and C. Fruchart, "Hypodiploidy is a major prognostic factor in multiple myeloma," Blood, vol. 98, no. 7, pp. 2229-2238, 2001. 